J. Dairy Sci. 100:6008-6008

https://doi.org/10.3168/jds.2017-100-7-6008

(c) American Dairy Science Association ${ }^{\circledR}, 2017$.

\title{
Corrigendum to "Genetic parameters for lactose and its correlation with other milk production traits and fitness traits in pasture-based production systems" (J. Dairy Sci. 100:3754-3766)
}

\section{Haile-Mariam and J. E. Pryce}

In Table 5 (page 3764), the correlation between EBV for lactose percentage and SCC should be -0.15 , not 0.15 . The corrected table is shown below, with the corrected value in bold.

The authors regret the errors.

Table 5. Correlations between EBV for lactose percentage or yield and fitness traits (fertility, survival) and indicators of fitness traits (angularity, SCC, udder depth, pin width, and milk yield) obtained from routine national genetic evaluation

\begin{tabular}{lcc}
\hline Trait with EBV & $\begin{array}{c}\text { Lactose } \\
\text { percentage }\end{array}$ & $\begin{array}{c}\text { Lactose } \\
\text { yield }\end{array}$ \\
\hline Fertility & 0.08 & -0.27 \\
Overall survival & 0.07 & 0.08 \\
SCC & $\mathbf{- 0 . 1 5}$ & 0.0 \\
Angularity & -0.13 & 0.14 \\
Udder depth & 0.05 & -0.06 \\
Body depth & -0.05 & 0.03 \\
Pin set & 0.05 & 0.16 \\
Milk yield & 0.06 & $0.83^{1}$ \\
\hline
\end{tabular}

${ }^{1}$ Correlation of milk yield and lactose yield calculated from the same data for both traits was 0.96 .

\section{REFERENCES}

Haile-Mariam, M., and J. E. Pryce. 2017. Genetic parameters for lactose and its correlation with other milk production traits and fitness traits in pasture-based production systems. J. Dairy Sci. 100(5):3754-3766. https://doi.org/10.3168/jds.2016-11952. 